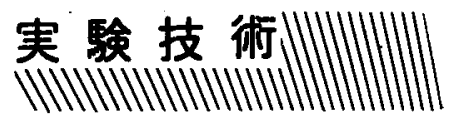

固定化 DNA による転写の動的解析

国立寈伝研 - 九大大学院医学研究科 寺田博之

国立遗妘研 嶋本伸雄

\section{固定化 DNA}

樹脂やカラムマトリックスにDNA を固定化する技 術は歴史が古く，DNA セルロースやDNA アガロース カラム ${ }^{1)}$ に起源を持ち, 現在もDNAに親和性を持つ 蛋白質を精製するために用いられている，この方法は， DNAを結合の対象となるリガンドとして扱っている が，もっと積極的に，DNAを転写の鋳型のように cofactorとして用いたり，組み換えやDNA 合成の基 質として用いることも可能である.

\section{DNA を端で固定化する方法}

固定化されたDNAをこのように積極的に用いる目 的には，DNAを特定の部位で樹脂に強固に結合し， DNAのそれ以外の部分の機能を損なわないようにし なければならない，そのなかで最も単純な方法は， DNAをその一端で固定する方法である．

DNAの端を固定する方法は，オリゴ DNA 合成に用 いられるようなやり方もあるが, 工業的規模の生産で はない限り, 非共有結合でおこなうやりかたが最も便 利である.この方法で現在開発されているものは,ビ オチン・アビジンの結合を利用するが2), 抗原・抗 体3)の結合を利用するものである. われわれは，バク テリオファージT 4 の DNA ポリメラーゼを利用して, ビオチン化ヌクレオチドをDNA の端に導入し，アビ ジンを介して樹脂に固定する方法を用いている（図 1 ).

ほとんどの制限酵素による切断部位で固定化が可能 である. 100-10kbp なら，90\%以上の効率で固定化が 可能であるし，45kbの $\lambda$ DNA でも50\%以上の固定化 が可能である.

\footnotetext{
Immobilized operon as a kinetic tool for analyzing transcription.

Hiroyuki TERADA ${ }^{1.2}$

Nobuo SHIMAMOTO ${ }^{1}$

1 DNA Research Center, National Institute of Genetics

2 Graduate School of Medicine, Kyushu University
}

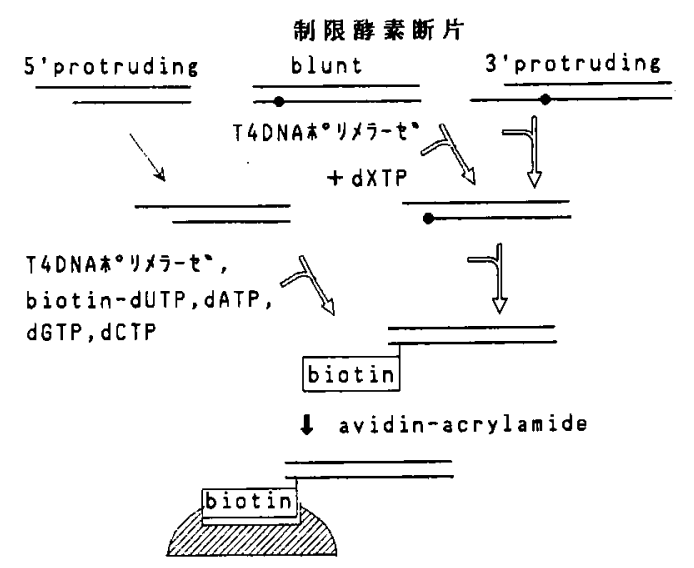

図1，ビオチン・アビジンを用いた固定化オペロンの作製 法

・印は DNA ポリメラーゼのエキソヌクレアーゼII 型活性で削る限界点で塩基は $\mathrm{dXTP}$ と同じ

このように固定化されたDNAは，固定化部位から 18b しか離れていない制限醳素部位でも，切断が可能 で，固定化による立体障害は，固定化部位以外ではほ とんど無いことがわかる.また，ビオチン・アビジン で固定化したDNAは $4{ }^{\circ} \mathrm{C} て ゙$ 保存すると，半年は安定 で解離は観測できない。

\section{固定化オペロンによる新しい方法論}

固定化オペロンの転写におけける用途は 3 つある. 第 一は，精製された再構成系で，転写の機構を酵素学的 レベルで研究することである. 後述するように，新し い速度論的方法を用いることにより, 動的機構の研究 に寄与することができる，第二は，粗抽出液からなる 転写系に用いることにより，転写複合体の精製や複合 体の構成要素の同定, 低分子の取り込み離脱の様子等 を調べることができる，第三は，架間にDNAを固定 することにより RNAポリメラーゼのような DNA 関 連酵素の連動を 1 分子で観察するという，1 分子タイ ナミクスへの応用である.

希釈による反応の停止と転写複合体への調節因子の結 合・解離

固定化オペロンで便利になった速度論的方法の第一 は，希釈によって反応を停止することである.すべて， 酵素反応が継続するためには，基質がある程度の濃度 存在していなければならない.つまり, 反応中に反応 液を希釈して，基質濃度を低下させれば，実質的に反 応は停止するはずである. 希釈液は, なんでもよいが 反応に用いた緩衝液そのものでもよい。これを高速希 釈法 (rapid dilution) という（図 2 の一部に示す). この方法の最大の長所は, 反応液の成分を変えすに， 


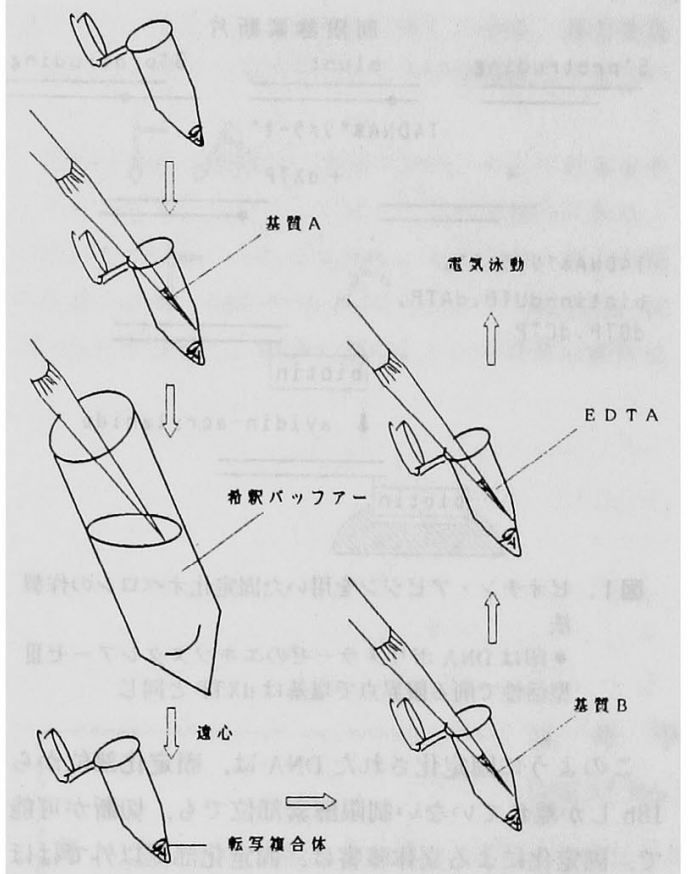

图 2、基質置換法のやり方 前半（左㑚）の部分は，高速希釈法である

反応を停止できることである，合成されたRNAだけ を観測するのならどの様な手段でも良いが，転写複合 体と遊離のタンパク質を分離する場合などでは, 反応 を停止する環境も重要である．同じ緩衝液で希釈する ことによる反応の停止は，この点では最も優れている。 しかし，この希釈による方法の欠点は, 大きな体積 の增加である. 例えば, 原核生物の RNA ポリメラー ゼの場合，才プティマルな条件の反応を停止しようと すると，1,000倍以上の希釈が必要になる. $10 \mu 1$ で

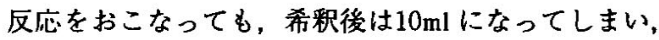
電気泳動による分析などでは，このままでは濃度が不 足する場合が多い. 固定化オペロンの長所は, この次 の濃縮のステップが簡単であることである. 低速の遠 心でもろ過でも数秒から数分の間に完了し，簡単にも との $10 \mu 1 に$ に濃縮することができる.

もし，1,000倍希䣋の後にもとの体積まで固定化才 ペロンに結合したものを濃縮できたとすると, 固定化 オペロンに結合していない転写調節因子は， $99.9 \%$ 除 かれていることになる.このようにして, 転写複合体 に脱着する転写調節因子の結合と解離の様子を調べる ことができる．我々は，大腸菌 RNA ポリメラーゼの のサブユニットの転写複合体からの解離の時問経過を 求めるのに成功した4)。このやり方のコッは、樹脂へ の蛋白質の吸着を防止することである.
基質置换法と RNA ポリメラーゼの ATP の要求性5)

希釈によって反応を停止した転写複合体は，再び基 質を添加すると RNA 伸長を再開することがわかった。 このとき，基質の代わりに基質アナログを加えると， アナロクの RNA 伸長に対する効果を見ることができ る.また逆に，基質アナログを最初に加えておき，希 釈によって反応を停止し，濃縮後に基質を加えると， 転写の開始と伸長の初期に対するアナログの効果を見 ることができる.この方法を基質置換法 (substrate substitution) と名づけた（図 2 )。

このような一連の実験で, 大腸菌の RNA ポリメ ラーゼを用いて，ATPと $\beta ， \gamma$ 非水解 ATP アナログ を置換したものについて, RNA 産物のオートラジオ グラムを図 3 に示した. 第一の反応を $5 \mu \mathrm{M}$ のラベ ルされた UTP と0.1mM の他の 3 つの基質を入れて20 秒，第二の反応を $0.1 \mathrm{mM}$ の全てラベルされていない

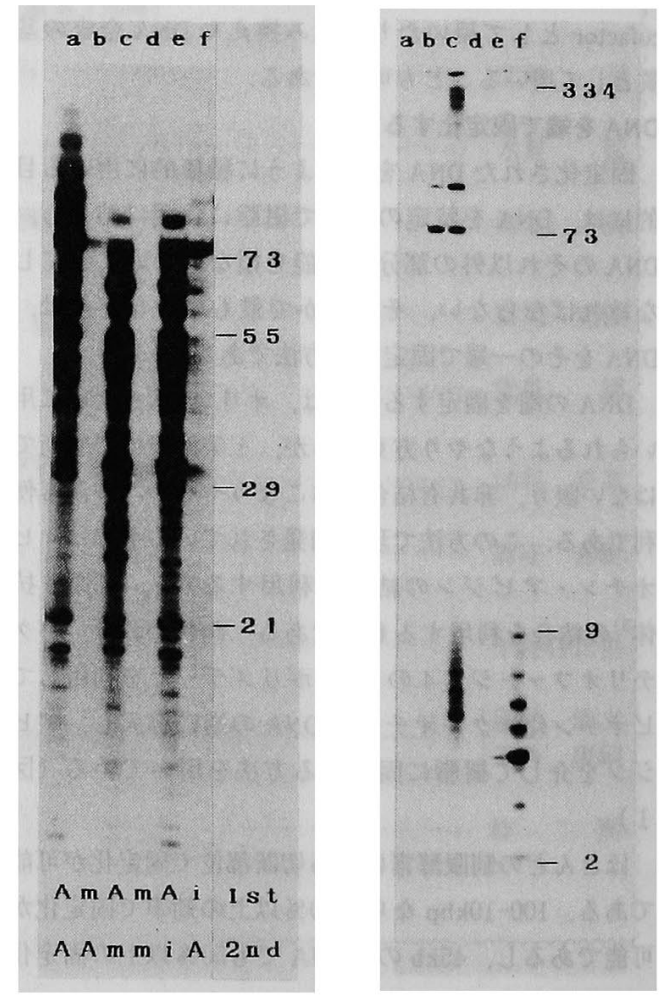

図 3. 大腸菌 RNA ポリメラーゼを用いたATPと $\beta$ ， $\gamma$ 一 非水解 ATP アナログの基質置換

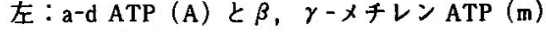

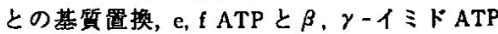
(i) との基質置换 添加の順は図の下に示す.

右：a-c 20秒， 2 分, 20分での ATP 存在下での RNA 産物 $\mathrm{d}-\mathrm{f} 20$ 秒, 2 分, 20分での $\beta, \gamma-$ メチレンATP存在下でのRNA 産物 
基質を用いて 5 秒㧍こなった。つまり，第一の反応で ラベルが取り込まれたRNAがどのくらいあって，第 二の反応でそれが伸びるかどうか見ているのである.

この図で明らかなように，RNAの伸長には少しし かアナロクの効果は無いが (左 a, c, e), 転写の開 始と伸長の初期にたいしては大きな阻害効果を及ぼす (左 b, d, f). 阻害は, 合成速度の低下という形で なく, 長鎖 RNAの本数が隇少するという形で現われ る.ここで用いた $\lambda \mathrm{P}_{\mathrm{R}}$ プロモーターからはA から転 写が開始するので (AUG・の順) ATPのアナログの 効果は転写開始と RNA 伸長の初期との 2 つの段階に 効果を及ほし得る．そこで，転写の開始は，ATPよ り高い親和性を持つジヌクレオチド $\mathrm{CpA}$ で代用し, RNA 伸長の初期のみ ATP アナログでATP の代用を した実験をおこなった，図には示していないが，転写 開始を $\mathrm{CpA}$ でおこなっても，アナログでは長鎖 RNA になる本数が減少した，RNA 伸長の速度は，ATPの 場合と比べてそれほど影響を受けなかった。一方，第 一の反応のみを連続して転写をおこなったとき，アナ ロクの存在下で，短鎖 RNA の蓄積が観測されたこと から (右 $\mathrm{f})$, 減少したRNAは，短いままで転写複合 体から解離していると推定された。

RNA ポリメラーゼは，RNA 合成にヌクレオシド三 燐酸の $\alpha, \beta$ 結合を要求するが, $\beta, \gamma$ 結合の役割は

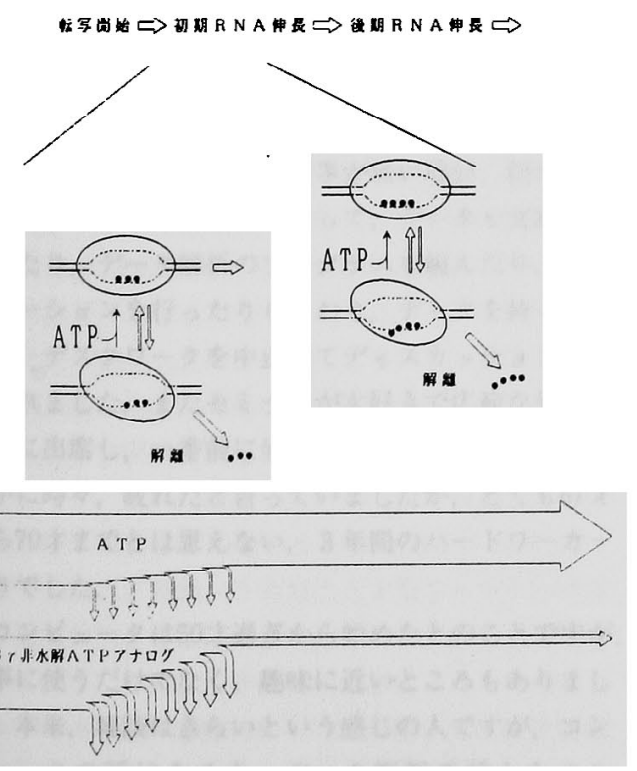

图 4. 原核RNA ポリメラーゼの RNA 伸長反応における ATP の役割

$\operatorname{ATP} の \beta, \gamma$-結合が無いと RNA は短いままで眖 落する量が增加する。
自明ではなかった。一方，ほとんどの ATPを基質と する反応は， $\beta, \gamma$ 結合を要求する. ATPase やキ ナーゼなどすべてこの範畴にはいる，果して，RNA ポリメラーゼがこのような酵と同じ形で ATP を要 求するかどうかは20年来の問題であった，我々が得た 結果は，図4のモデルで矛盾なく説明できた. ATP が加水分解されているのか，キナ一ゼの基質になって いるのか，それとも分解されずにただアロステリック エフェクターとなっているのか, は不明であるが, ATP がRNA 伸長の初期に長鎖 RNA を作れるように 䤃素のコンフォメーションを維持していると考えるこ とができる.

以上の結果は, 大腸菌の RNA ポリメラーゼで得ら れたものであるが，大腸菌特有の現象であるのか， もっと一般的な現象なのかを確かめるために, 最も構 造が簡単な RNA ポリメラーぜと考えることができる， バクテリオファージの RNA ポリメラーゼを用いて，

同様な実験をおこなった，都合の良いことに，T７と T 3 ファージの典型的なプロモーターでは，RNA は GGG からスタートして，A を最初は含まない。従っ て, 固定化才ペロンとRNA ポリメラーぜを湿ぜて, プロモーター・ポリメラーゼ複合体を作るときに, GTPを入れておいて GGG を合成させれば，転写の開 始は予完了させておくことができる. 実験結果は, 基本的には大腸菌の場合と同様であった. 転写の伸長 のスピードに多少アナログの効果は出たが，その効果 を差し引いても，長鎖 RNAの本数の減少が観測され た.SP 6 RNA ポリメラーゼに拈いても、T 7，T 3 と 似た結果を得た。つまり, 原核生物の RNA ポリメ ラーゼは, 検討した酳素はすべて図 4 のモデルで説明 できるものであった。

固定化オペロンを粗抽出液に用いた転写の各段陼の同 定

真核細胞の転写にも ATP は必須である ${ }^{6)}$.このこ とを調べるために, Hela 細胞の核抽出液を用いた例 がある.アデノウィルスの Major late プロモターを含 むDNA を固定化したものを抽出液と混合し，転写複 合体を形成する. 核抽出液, 複合体形成期, 最初の基 質を加えたとき，2番目の基質を加えたとき，と段階 を追ってATPを加えた．この結果， 2 番目の基質と 同時に ATP が要求されることが分かっだ．つまり， 転写開始か, 伸長期の初期にATP が要求される。こ のことは，原核生物の RNA ポリメラーゼが， RNA 伸 長の初期にATP を要求することと比較すると興味深 い. 
固定化オぺロンによる DNA の立体槽造の保持を利用 した技術

両端を固定化したDNAを用いると，固定化された ままで超らせん構造をとらせることが可能である。ま た，DNAを一定の方向に固定化することもできる． さらには，レーザーを用いた光ピンセット法で，1本 の DNA の両端を捕捉することも可能になりつつある. このような技術は，単にDNAのコンフォメーション が転写に及ほす影響を精密に測定するだけでなく，分 子1つの動きを記録しようという1分子ダイナミクス に応用が可能である。この技術を用いて，RNAポリ メラーゼやDNA ポリメラーゼの動きを直接観察する ことができる. 現在の技術の壁は，DNAを一定の空 間配置に固定化することであり，我々は固定化 DNA の技術をこの方面に広げるべく努力している.

\section{固定化の効果}

固定化 DNA を，転写の鋳型として用いる固定化才 ペロン法は，すでに述べたように，新しいキネティッ クスやダイナミクスを可能にする沉用技術である．固 定化されたDNA を用いることによって，いろいろな アーテファクトを持ち这むことが有り得ることは，他 の技術と同様である. しかし，細胞内で DNA は決し て完全に遊離状龍で存在しているのではない。もちろ ん，染色体 DNA は核マトリクスに固定化されている であろうし，この事情は，原核生物の遺伝子でも同様
である. 比較的遊離状態に近いと思われるエピソーム の DNA も，部分的に固定化されている可能性は否定 できないのである. 従って，固定化オペロンによる アーテファクトは，固定化自身によるのではなく，そ の時に用いた固定化の手段が原因になっている場合が 多いであろう。いろいろな工夫が試みられるべき，楽 しい分野にしたいものである.

\section{最後に}

著者の一人であります寺田博之がこの執筆中 7 月 8 日に逝去致しました．故寺田君の冥福を祈り，同君の 研究成果に感謝しつつ本報をまとめました。

\section{文献}

1) Alberts, B., Herrick, G. : Methods in Enzymology Vol. 21 (1971) pp 198-201. Academic Press

2) Langer, P. R., Waldrop, A. A., Ward, D.C.(1981) Proc. Natl. Acad. Sci. U. S. A. 77, 6633-6637

3）例えば, DIG ラベリンクキット Boeringer Mannheim Reagent Catalogue

4) Shimamoto, N., Terada, H. Fujioka, M. (1991) J. Cel. Biochem. Supplement 15G 245

5) Fujioka, M., Hirata, T., Shimamoto, N. (1991) Bioche. mistry 30 1801-1807

6) Conaway, R. C., Conaway, J. W. (1988) J. Biol. Chem. $2632962-2968$

7) Arias J. A., Dynan, W. S. (1989) J. Biol. Chem. 264 3323-3329 